\title{
Transformações da Paisagem e a Memória em Camorim*
}

\author{
Landscape Transformations and Memory in Camorim
}

\section{Luz Stella Rodríguez Cáceres ${ }^{* *}$}

\section{RESUMO}

Um importante elemento identitário para os habitantes do bairro Camorim é a capela de São Gonçalo de Amarante construída em 1625, ícone da arquitetura rural colonial do Rio de Janeiro e tombada como patrimônio estadual em 1965. A igreja e a paisagem que a rodeia têm passado pelas modificações que o tempo e as atividades humanas e não humanos Ihe imprimem. $O$ interesse e empenho da comunidade católica do bairro na restauração da capela no final da década de 1990 e as atuais apropriações simbólicas do espaço circundante da igreja por parte de um grupo quilombola oferecem um marco para explorar as relações que se tecem entre memória, mudança, materialidade e paisagem. 0 cenário de fundo são as abruptas transformações urbanísticas que vêm acontecendo na região, alvo da expansão urbana carioca e as inquietações que dito momento desperta nos habitantes do bairro.

Palavras-chave: Memória. Patrimônio. Paisagem. Restauração. Mudança.

\section{ABSTRACT}

An important identity element for residents of the neighborhood Camorim is the chapel of "São Gonçalo de Amarante" built in 1625, icon of the rural and colonial architecture in Rio de Janeiro and protected by law as a state heritage in 1965. The church and the scenery around have been going through transformations brought by the time and the human activities and not human activities. The concern and

\footnotetext{
*Este trabalho contou com o apoio da_Fundação Carlos Chagas Filho de Amparo à Pesquisa do Estado do Rio de Janeiro FAPERJ

** Antropóloga pela Universidade Nacional de Colômbia. Doutora em Geografia pela Universidade Federal do Rio de Janeiro. Pós-doutoranda no Departamento de Antropologia Cultural do Instituto de Filosofia e Ciências Sociais IFCS/UFRJ e pesquisadora do Laboratório de Antropologia da Arquitetura e o Espaço LAARES. http://www.laares-ufrj.com/
} 
endeavors of Catholic community in the neighborhood in restoring the chapel in the end of the 1990s and the current symbolic appropriations of the church surroundings by a quilombola group offers an important subject matter to explore the relations between memory, change, materiality and landscape. The background scenery consists in abrupt urban transformations that have been happening in the region because of Rio's urban expansion and also in worries that arise among the neighborhood residents.

Keyword: Memory. Heritage. Landscape. Change.

\section{Introdução}

As relações entre, memória, paisagem e materialidade serão exploradas a partir da etnografia realizada em Camorim, um bairro da zona oeste de Rio de Janeiro, parte da denominada planície de Jacarepaguá. Até ha poucos anos aquela região era associada a um refugio bucólico semi-rural nas margens da metrópole. Desde 2010 o grupo de bairros localizados às margens da Estrada dos Bandeirantes passou a ser o novo polo do desenvolvimento urbano carioca, produzindo radicais mudanças na paisagem. No cerne da aceleração e intempestividade dessas transformações encontram-se as relações que os moradores tradicionais estabeleceram com o entorno e os significados que lhe têm atribuído.

Sem esquecer que o pano de fundo destas transformações é a especulação imobiliária que tomou a cidade por conta dos megaeventos, me interesso por analisar o papel da materialidade na construção da memória no intuito de resistir às mudanças impostas. Nesse sentido resulta útil explorar as possibilidades analíticas da paisagem como categoria nativa. A importância da capela de São Gonçalo do Amarante nessa discussão se dá não só pela localização dela em uma paisagem singular, se não também por se erguer como contraponto, símbolo de permanência num lugar onde as atuais políticas urbanísticas impõem a sensação aos habitantes de que todo parece destinado a transmutar.

A igreja seria vestígio material da história de Jacarepaguá e o domínio que sobre essas terras, conhecidas outrora como a Planície dos Onze Engenhos, tiveram a família de Mem de Sá e posteriormente os monges beneditinos. Contudo, esse patrimônio, que hoje aparece aos nossos olhos como um remanescente preservado do passado colonial, também esteve submetido às mudanças do tempo e não foi erguido sem ambiguidades.

Para esta reflexão proponho situar ao leitor apresentando uma descrição do bairro Camorim, seus habitantes e as políticas urbanistas responsáveis pelo atual crescimento. Em seguida, a partir da visão local exploro a forma como essas mudanças são vivenciadas pelos atuais moradores, onde a paisagem mais que um objeto seria é um eixo que permite-nos pensar em alterações e continuidades ao entrelaçar natureza e cultura . Posteriormente vou 
me concentrar na descrição do processo de tombamento e restauração da capela, os cruzamentos entre memória e paisagem e as diferenças existentes entre os patrimônios oficiais e as formas como são assumidos localmente. Considerando que o patrimônio é construído social e culturalmente, sempre vinculado à noção de herança coletiva ou individual, ancorado a determinadas concepções de temporalidade e movimentado em torno de objetos de determinada cultura material (GONÇALVES, 1996).

\section{Camorim, um bairro em transformação}

As relações entre paisagem e memória sempre serão o resultado de contextos temporais e locais específicos. Em alguns momentos ambas categorias parecem sincronizadas, amarradas a um determinado tempo. Simon Shama (2009, p.17) considera que uma paisagem em movimento parece um lugar propicio para se relacionar com a memória. "Antes de poder ser um repouso para os sentidos, a paisagem é obra da mente. Compõe-se tanto de chamadas de lembranças, quanto de estratos de rochas". Porém, em outras circunstâncias essas noções podem se ver distanciadas. Eventos que aceleram o movimento e a transformação da paisagem podem ter como efeito de resistência um apelo à memória e o passado. Dai que a análise da paisagem como categoria nativa precise ter um marco temporal que não é a temporalidade da ciência da paisagem ou da ecologia. A paisagem como produto cultural é inventada em cada momento histórico ou seja, "descobre-se" a beleza de lugares em determinados períodos e épocas, (CAUQUELIN, 1990, p. 94-95). Deste modo, nenhuma regra sobre a relação entre paisagem e memória pode ser ditada; a experiência etnográfica é trazida aqui para oferecer nuances possíveis entre essas duas categorias.

O caso de Camorim é abordado considerando os impactos gerais que vários bairros da zona oeste do Rio de Janeiro vêm sentindo a partir do grande boom imobiliário, produto dos novos parâmetros urbanísticos permitidos pelo Plano de Estruturação Urbanística ${ }^{1}$ e os projetos de adequação da Baixada de Jacarepaguá para os Jogos Olímpicos em 2016 implementados pela Prefeitura da cidade. A aprovação do PEU foi fundamental para que a prefeitura pudesse assumir os compromissos com o Comitê Olímpico Internacional (COI).

\footnotetext{
${ }^{1}$ A Câmara dos Vereadores do Rio de Janeiro aprovou em 2009 o conhecido PEU das Vargens, nele a região foi dividida em 11 setores e para cada um se estabeleceu o gabarito máximo variando entre dois e 18 andares, o projeto instituiu o mecanismo da outorga onerosa: com o pagamento de uma contrapartida à prefeitura, $o$ construtor tem a opção de erguer prédios com mais pavimentos. Os pesquisadores que estudam os impactos do PEU das Vargens na região e arredores estimam que esta pode receber mais de um milhão de pessoas. Em 2010, de acordo com o Censo, viviam 43.259 pessoas no Camorim, em Vargem Grande e Vargem Pequena (NAME; MONTEZUMA; GOMES, 2011). Ainda o numero de novos habitantes não chega nesse patamar mas se incrementou o suficiente para deixar inquietos aos atuais residentes.
} 


\section{Imagem 1 - Mapa da localização do Camorim}

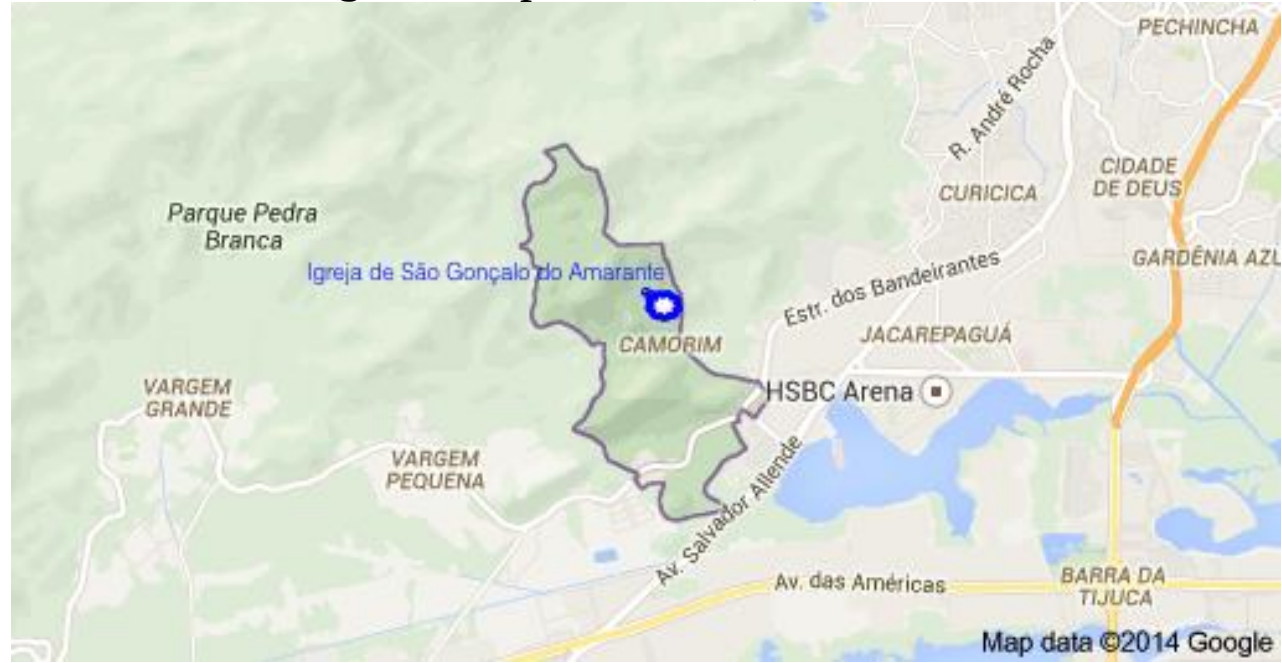

Fonte: Google Maps

Camorim $^{2}$ é um dos bairros considerados pelo PEU, próximo ao Centro de Convenções Riocentro, também está localizado na área de impacto dos futuros Parque Olímpico, Vila Olímpica, Centro Metropolitano da Barra e Cidade do Rock. Contudo, antes de se identificar com esse novo polo de desenvolvimento urbano em gestação, os habitantes de Camorim encontram na Capela de São Gonçalo do Amarante e no Maciço da Pedra Branca importantes referências de identidade cultural e que adquirem especial importância como fontes de permanência num contexto em que tudo parece mudar de forma precipitada. Esses dois elementos colocam o bairro conexo a um tipo de sossego que os moradores definem por uma escala na que todos se conhecem ou são familiares e à qual corresponde uma ordem moral. Esse aconchego também se dá pela proximidade do mundo natural, dada pela presença do Parque Estadual da Pedra Branca.

A alegada falta de espaço em outras áreas da cidade e os investimentos em

\footnotetext{
${ }^{2}$ Para chegar em Camorim desde a Central do Brasil pode se tomar ônibus, cujo trajeto é de aproximadamente duas horas em meia. O percurso mais rápido se faz pela linha Amarela passando pela Cidade de Deus até a Estrada dos Bandeirantes, perto do numero 8000 vira-se à direita para tomar a Estrada de Camorim, um caminho que passa pelo largo da Capela de São Gonçalo do Amarante e que sobe até uma das entradas do Parque Estadual Pedra Branca. As caraterísticas das casas e residências vão mudando na medida que vai se subindo pelo estrada na direção da encosta. Na planície, perto da estrada dos Bandeirantes e nas ruas que desembocam na estrada de Camorim há ainda casas de dois andares em centro de terreno com jardins e alguns condomínios. Na viera da estrada, perto do rio a mão esquerda se vislumbram terrenos "vazios", uma empresa e alguns sítios de veraneio e de eventos e festas. Após passar o largo da capela e na mão esquerda da estradinha que vai se tornando íngreme o observador começa a vislumbrar as moradias mais populares, a grande maioria em tijolos e sem pinturas que se sucedem umas às de forma compactada. Desde o mercado na esquina da estrada dos Bandeirantes onde esta o ponto de ônibus até a capela há 20 minutos a pé, mas também pode-se chegar ao largo de van e de moto-taxi.
} 
infraestrutura e transporte por conta dos Jogos Olímpicos de 2016 transformaram a antes longínqua Estrada dos Bandeirantes em endereço atrativo para o mercado imobiliário por ser uma via bem extensa e com muitas áreas ainda não edificadas. A calma e tranquilidade que definem para os habitantes o modo morar em Camorim começaram ser transtornadas pelas rápidas mudanças urbanísticas, e esse panorama configura pontos de tensão entre um peculiar universo cultural e ambiental a ser preservado e a voragem urbanista e modernizadora na qual o mercado imobiliário vem apostando.

O atual é um momento de transição no que o espaço é objeto de intensa valorização na condição de mercadoria, através da realização da propriedade privada do solo urbano como condição para sua reprodução. Essas mudanças são interpretadas de diferentes formas e segundo os depoimentos de alguns moradores, revelam maneiras de percepção da paisagem. Seu Moacir, por exemplo, vê nessas transformações "a evolução do logradouro", William, um motoboy que presta seu serviço de passageiros entre o ponto do ônibus e o alto Camorim, vê a chegada de novas pessoas como fonte de incerteza, "é bom porque movimenta o mercado, mas nunca se sabe que tipo de gente é o que vai vir". Pela sua parte, Sirlene, a responsável da biblioteca comunitária, se preocupa com a quantidade de carros e os perigos que estes oferecem para as crianças na rua, mas ressalta que por outro lado se vem investimentos públicos antes não sonhados, creche, saneamento básico, calçamento etc. Adilson, coordenador da associação cultural, lamenta principalmente a descaracterização da paisagem, e teme pela integridade da igreja de São Gonçalo e pelo apagamento que as memórias da escravidão que repousam na paisagem.

Contudo, esse processo de urbanização é de longa data. Segundo o históriador Leonardo Soares a pressão para a expansão urbana pode se datar desde a década de 1940. O Plano urbanístico para a Barra da Tijuca e Jacarepaguá de Lucio Costa em 1969 teve importantes consequências no processo de des-ruralização da zona oeste (SOARES; RIBEIRO, 2007, SOARES, 2011, 2012; FRIDMAN, 1999), que veio a se consolidar com o PEU aprovado em 2009, o qual permitiu mais construções na área que já vinha passando por uma especulação imobiliária informal.

Camorim não é um lugar homogêneo e pelo contrário sua população é muito variada social, racial e economicamente. Ali têm sua residência descendentes dos ex-escravos do engenho dos beneditinos, os descendentes dos antigos lavradores e pequenos agricultores do outrora "sertão carioca", os despossuídos do extinto Banco de Crédito Móvel. Algumas pessoas possuem propriedades registradas, enquanto outras nem tentaram legalizar suas posses. Também habitam o bairro os migrantes que podem se classificar por ondas, os portugueses, os nordestinos, os cariocas da zona sul e recentemente os haitianos que vêm formando ali um novo núcleo.

Além do mais, o bairro foi povoado por pessoas de origem urbana que buscaram novas formas de ruralidade e outras de baixa renda que segundo Soares (2011) acharam nas 
encostas da mata Atlântica, um "cantinho" para morar, livre do aluguel, graças à dica de algum parente ou amigo que divulgou a oportunidade de aquisição de um terreno sem a comprovação do registro geral de imóvel ou daquele que foi cedendo parte de seu chão ou moradia para a construção de uma casa, um novo andar, uma laje e até um "puxadinho". É o caso do Seu Moacir Couto, um dos moradores mais velhos do Alto Camorim, que a seus 91 anos se orgulha de contar "dei origem a esta favela toda", referindo-se à comunidade do Marimbondo. Ele conta "fui cedendo cada um dos 48.400 metros quadrados do alqueire que herdei do meu pai, cedia terra para quem pedia, hoje não há mais nada a ser loteado, resta construir para cima". Suas palavras revelam que mesmo sem poder se expandir mais na horizontalidade o crescimento da comunidade ainda não parou.

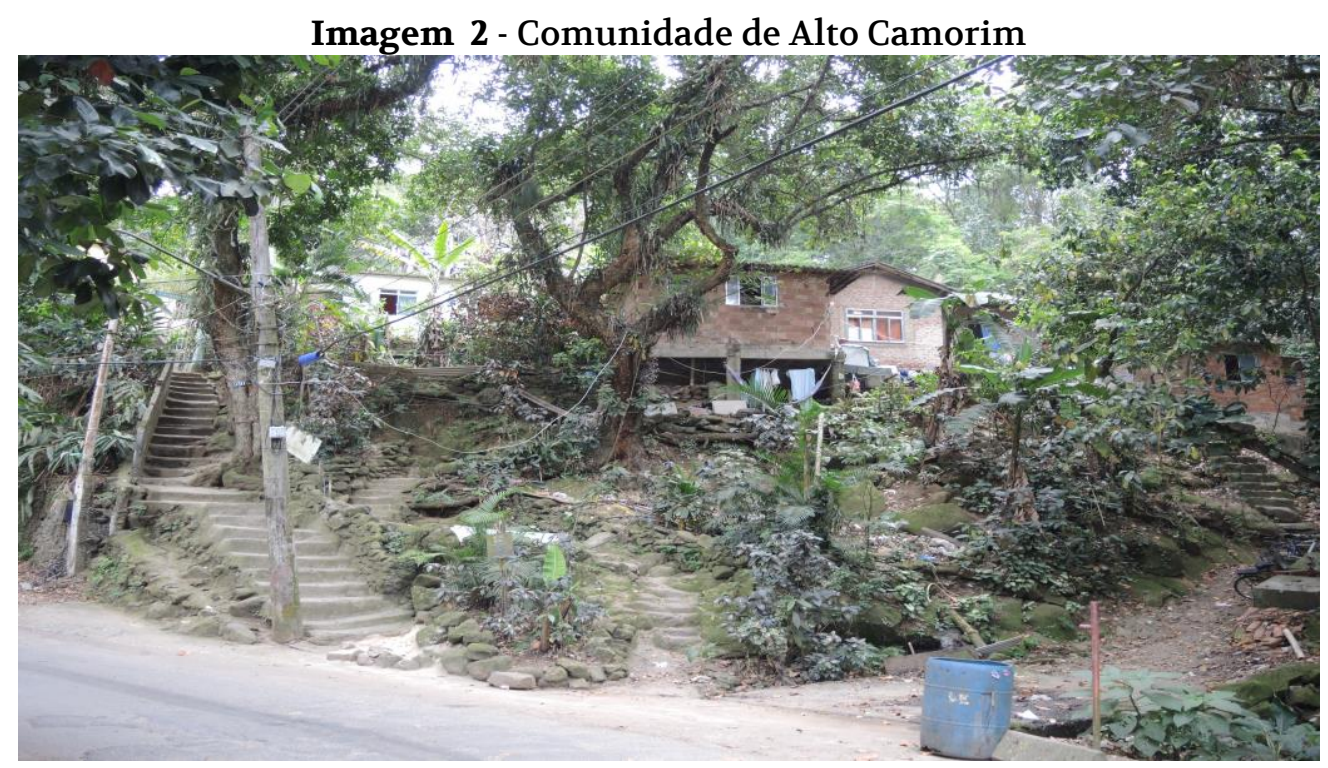

Fonte: Luz Stella Rodríguez Cáceres 24/05/2014

Imagem 3 - Casas no Bairro Camorim

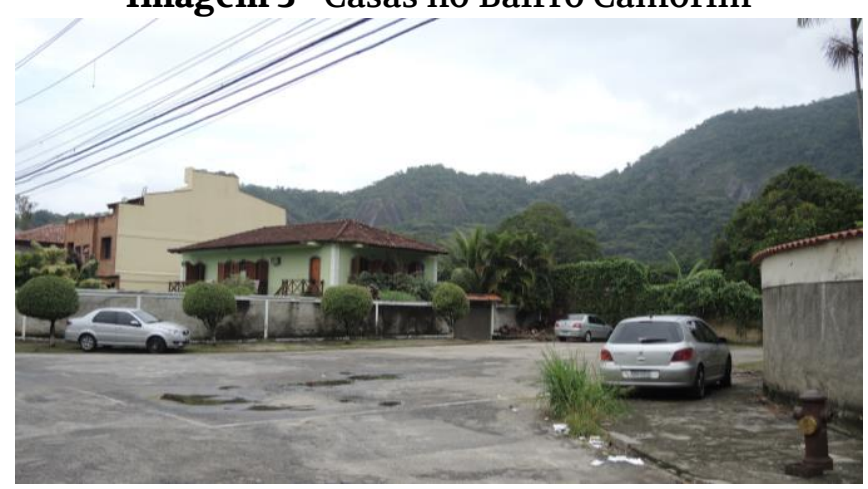

Fonte: Luz Stella Rodríguez Cáceres 24/05/2014 
Imagem 4 - Rua do Bairro Camorim.

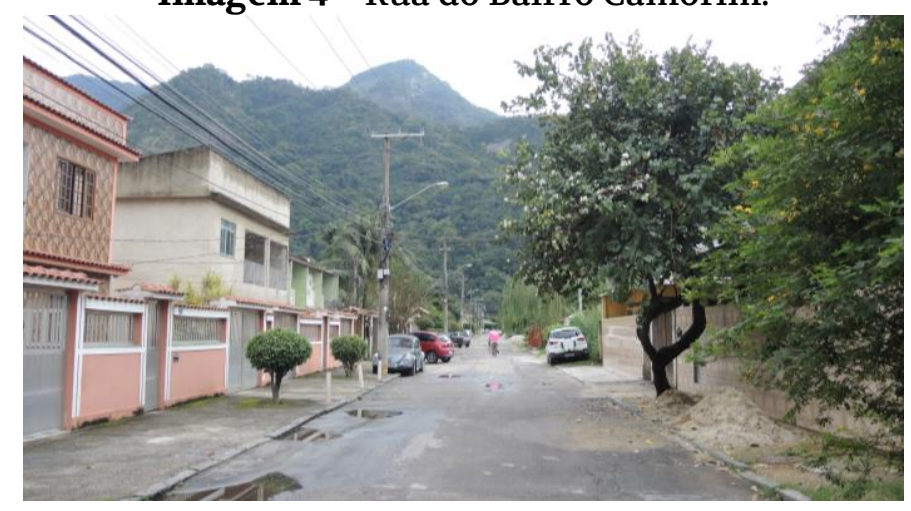

Fonte: Luz Stella Rodríguez Cáceres 24/05/2014

Também existem em Camorim sectores de classe média e alta que ali estabeleceram sítios de veraneio ou casas em condomínios. Agora a construção dos novos edifícios o perfil dos novos moradores promete agregar ainda outras diferenças populacionais, já se vê pelo bairro moradores de certo poder aquisitivo e aqueles que provêm do programa de moradia social do governo federal "Minha Casa, Minha Vida". É no Parque Carioca na Estrada dos Bandeirantes, por exemplo, onde agora reside uma parte dos moradores que foram removidos da Vila do Autódromo, cujos condomínios fechados deveram oferecer outros padrões de sociabilidade e relação com a paisagem.

A diversidade nas formas de habitar e os distintos tipos de habitantes leva a que a metamorfose espacial não seja interpretada de forma unânime. Porém o denominador comum à maioria desses moradores é o orgulho sentido pela sua proximidade à capela de São Gonçalo do Amarante e o temor maior que sua ambiência venha a ser alterada pelas mudanças urbanísticas.

Minha inserção no campo aconteceu em 2010 quando assisti uma reunião entre alguns moradores do bairro e funcionários de INCRA. Nessa ocasião os habitantes expuseram a problemática que os unia; a falta de espaços comunitários públicos e o fato das atividades lúdicas vir acontecendo na própria rua, onde as crianças disputavam-lhe espaço a carros e motos. Eles também manifestaram o descontentamento que sentiam após a elevação de altura de um muro num terreno à mão esquerda da estrada de Camorim ao lado da igreja. Um terreno que sendo privado, também continha as marcas da escravidão.

É importante ressaltar que não todos os moradores de Camorim têm que passar pela capela, mas para os moradores da parte media e alta da estrada de Camorim a igreja é uma parada obrigatória, um importante espaço de circulação e socialização. Naquela reunião os participantes queriam saber os procedimentos para que o lugar fosse reconhecido como um quilombo $^{3}$, nos termos da atual legislação brasileira destinada a garantir os direitos

\footnotetext{
${ }^{3}$ Os desdobramentos advindos da questão quilombola não são abordados em profundidade nesta reflexão.
} 
territoriais para os descendentes de escravos que como tal se reconhecem.

Além disso, a queixa expressada pelos assistentes à reunião também continha uma demanda por espaço público para o lazer e para a prática de atividades de cunho cultural, como as que a Associação Cultural Camorim -Acuca-, promotora da reunião, procura incentivar entre as crianças e jovens moradores de um bairro que carece de qualquer equipamento urbano para estes fins. Para Maraci, outra moradora, o problema de Camorim era "a perda da paisagem", tal definição deixou-me instigada, pois não só apontava para uma determinada e particular relação desses moradores com o entorno ${ }^{4}$, se não que elucidava, as razões do empenho dos mesmos na preservação da mesma e cujo exemplo mais tangível era a recuperação da igreja de São Gonçalo do Amarante.

A paisagem como um algo suscetível de se perder remete às mudanças decorrentes do adensamento populacional, à especulação imobiliária e à própria temporalidade da paisagem, como é entendida por Ingold $(2000)^{5}$, as quais afetam as referências materiais que os moradores do bairro de Camorim enumeram como parte fundamental da sua identidade cultural. Assim, a elevação de um muro por parte do dono de um terreno do lado da capela, conhecido como Sitio Cronus é indicada por alguns moradores como o principio da perda "da vista, o céu e o sossego", já que a altura e comprimento do muro criaram um corte na paisagem, impedindo a vista para o maciço de Pedra Branca. Entretanto, o muro não é a causa da alteração na paisagem e sim a consequência mais visível de transformações de outra ordem.

Desde essa perspectiva, a categoria de paisagem com a qual os habitantes locais lidam daria ênfase à forma pictórica da paisagem ${ }^{6} \mathrm{e}$ às noções que priorizam a forma final e não o processo conjunto de incorporação. De acordo com Tim Ingold (2000) a paisagem, não é o resultado de uma determinada inscrição sobre um padrão pré-existente, se não um movimento de incorporação, onde forma e matéria, corpo e paisagem se geram a si mesmas mutua e simultaneamente. Parafraseando o autor, assim como os corpos não são formas dadas anteriormente, independentes dos seres que os constituem geneticamente, as formas da paisagem não são preparadas anteriormente para as criaturas ocuparem.

Longe de pretender, com isso, acusar o uso de uma noção fixa de paisagem ou uma certa negligencia do tempo contida na categoria nativa de paisagem que se expressa no fim "da vista, o céu e o sossego" é preciso ressaltar que a chamada "perda da paisagem" permitiu

\footnotetext{
${ }^{4}$ De acordo com Rachel Paterman Brasil (2014) a paisagem como "categoria nativa", pode servir de entrada a diferentes experiências de entorno. $O$ efeito desta abordagem é poder elucidar "modalidades" de conceber o entorno.

${ }^{5}$ Um componente importante da paisagem é o tempo, mas segundo Ingold (2000), este passa desapercebido porque tende-se a pensar a paisagem como concluída e estática, desconsiderando que habita-se nela através das atividades que se realizam, fazendo dela uma processo dinâmico

${ }^{6}$ Percepções vinculadas cheiros e sons, por exemplo, manifestam sensibilidades a elementos que não são associados direitamente à paisagem.
} 
direcionar a minha atenção para a maneira como a categoria de quilombo ${ }^{7}$ e paisagem foram mobilizadas pelos habitantes para falar sobre permanências e mudanças. Estas últimas representariam um risco contra o estilo de vida "tranquilo" que é levado ou à própria permanência dos habitantes. ${ }^{8}$

Deste modo, preservar a paisagem é preservar a própria existência, uma noção de paisagem estaria mais próxima das reflexões de August Berque, segundo as quais a paisagem não existe fora de nós, do modo que nós também não existimos fora da nossa paisagem, razão pela qual os discursos sobre paisagem sempre contêm uma certa auto referência (BERQUE, 1994, p. 27).

A angustia de alguns moradores frente ao repentino crescimento urbano se relaciona com o sentimento de que tais transformações não vêm sendo efetuadas por eles mesmos e os deixam no papel de meros espectadores e participantes passivos diante de um roteiro sobre o qual não possuem qualquer poder de influência. "Vemos o que esta acontecendo, mas não participamos, nada nos consultaram" lamenta Adilson Almeida. Em certo sentido, essa preocupação também se aproxima da paisagem de Ingold (2000) quem defende que esta não é uma entidade que contemplamos à distancia, senão o entorno modificado pelas ações cotidianas.

Para Ingold (2000) a paisagem é registro e testemunha das vidas e atividades das gerações que têm vivido dentro dela, deixando nela algo deles mesmos. Perceber a paisagem é um ato de lembrança da passagem do tempo e daqueles que vem habitando o lugar. Segundo o autor, a paisagem conta uma história, tanto para o arqueólogo como para o habitante. Adam opina que a paisagem seria uma crônica da vida e do habitar, ela envolve a vida e o tempo dos predecessores que por gerações têm sido parte na sua formação (ADAM, 1998 apud INGOLD, 2000). Deste modo, perceber a paisagem é também um ato de lembrança, onde o ato não é apenas chamar uma imagem interna estocada na mente senão relacionarse perceptivamente com um entorno que está, em si mesmo, repleto de passado.

Entretanto, a relação entre paisagem e memória não existe diretamente, nem se dá em primeiro grau, muito menos no contexto das rupturas modernas que conduziram para uma multiplicação de memórias coletivas (HALBWACHS, 2004). Sem essa noção, os "lugares da memória" de Pierre Nora, por exemplo, não teriam fundamento. Para ele os lugares topográficos, monumentais e simbólicos surgem onde a memória já não é mais contínua; eles seriam um depósito onde a sociedade confia suas lembranças (NORA, 1993, p. 7). Do que decorre necessariamente uma intencionalidade social no seu resgate e preservação.

\footnotetext{
${ }^{7}$ No entendimento de alguns moradores quilombo seria uma figura de proteção que iria além das figuras preexistentes de preservação com as que os habitantes convivem: o parque natural e a patrimonialização da igreja.

${ }^{8}$ Neste ponto é importante frisar que a remoção dos moradores na vizinha Vila do Autódromo foi um precedente importante, que anunciava até onde o poder público poderia chegar no caso de ocupações informais
} 
Mesmo que os lugares e paisagens permaneçam ai e estejam carregados de múltiplas memórias, para Nora a única relação ativa que pode-se manter com os lugares da memória é uma em segundo grau, feita da reativação daquilo que foi a história (HARTOG, 2009, p. 164). Daí a importância de entender os processos sociais por meio dos quais esses lugares vêm a ser elaborados e difundidos como depósitos de memórias sociais.

Nora (1993) conceitua os lugares de memória como um misto de história e memória, um plano híbrido, porque espiritual, simbólico, mas concreto, porque é um lugar onde se identifica um nascimento. Nesses lugares, a memória não precisa ser espontânea ou verdadeira, só precisa ter o sentido necessário de identidade, só precisa fazer entender de onde se veio para poder entender como se vive e quem se é. Para Nora (1993, p.13) "os lugares de memória nascem e vivem porque não há memória espontânea, [porque] [...] é preciso criar arquivos, organizar celebrações [...]". A restauração arquitetônica da capela de São Gonçalo do Amarante; os cuidados que cercaram o entorno e a paisagem do bem tombado vêm a tona para ampliar a discussão sobre a seleção e produção de lembranças e suas relações com a materialidade.

\section{A igreja de São Gonçalo do Amarante, uma biografia social.}

Quem se aventura pela Estrada do Camorim, depara-se no pé de serra com a capela de São Gonçalo do Amarante, uma pequena e singela edificação, cujas brancas paredes contrastam com o Maciço da Pedra Branca. Para os moradores a capela conta uma história, eles sempre afirmam "aqui há muita história" e "o passado habita aqui". O interesse etnográfico foi mais que pelo entendimento dessa história, pelas apropriações da mesma. Às informações coletadas em entrevistas somei a pesquisa de arquivo feita nos arquivos do Instituto Estadual do Patrimônio Cultural- INEPAC ${ }^{9}$ e reportes da imprensa, elementos que serviram para compor uma biografia social da capela ${ }^{10}$. $O$ resgate dessa biografia social revela a agencia humana na manutenção da materialidade do patrimônio e a estabilização de uma certa memória. Justamente por mediar relações entre "o passado e o presente, o cosmos e a sociedade, entre a cultura e os indivíduos, entre a história e a memória”, o patrimônio é um processo marcado pelas ambiguidades e é a elas que demos prestar atenção (GONÇALVES, 2005, p. 5).

\footnotetext{
${ }^{9}$ Processo 03/300.479/65

${ }^{10}$ Nos termos de Kopytoff (2010), a noção de "vida social" visa ao entendimento de como objetos e coisas se constituem simbólica e sensorialmente e as formas como podem ter inseridas suas trajetórias conforme os diferentes contextos discursivos, institucionais e emocionais em que venham a se situar. A vida social das coisas é uma chave de acesso aos significados que estão inscritos em suas formas, seus usos, permitindo um certo entender dos ciclos vitais de lugares e criações, assim como as transformações e reconstruções que insertam a problemática da memória no patamar das transações humanas que dão vida às coisas.
} 
Imagem 5 - Capela de São Gonçalo do Amarante, no fundo o maciço da Pedra Branca.

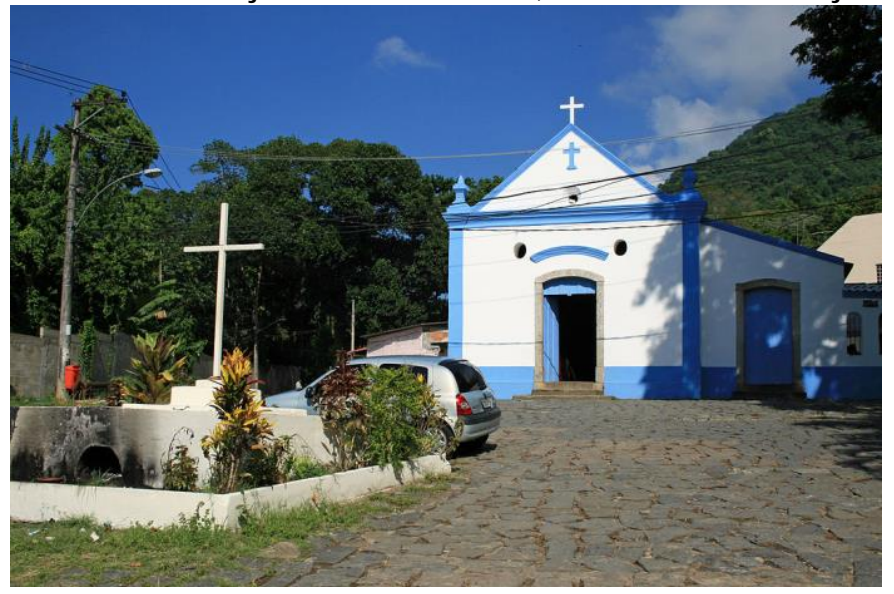

Fonte: Luz Stella Rodríguez Cáceres 24/08/2012

Nesse sentido, fatos importantes na vida da capela são sua construção, o esquecimento temporal que a submeteu ao abandono e deterioro, o tombamento como patrimônio do Estado do Rio de Janeiro em 1965, a restauração que em outro momento uniu à comunidade católica local no propósito de recuperá-la e as atuais apreensões respeito à sua ambiência. Sua inscrição no Livro de Tombo das Belas Artes do então Estado de Guanabara é um ponto de partida porque permite compreender as justificações e a recuperação histórica realizada.

O motivo principal para a patrimonialização da igreja foi considera-la uma mostra da arquitetura do século XVII, "uma marca da primitiva ocupação do Rio de Janeiro após a fundação da cidade e a vitória sobre os tamoios e franceses" (INEPAC, 2014). Trata-se de um tombamento no que se valorizou seu "valor de ancianidade", em palavras de Riegl (1984). Já que a capela sofria com as "modificações naturais" do tempo, o tombamento propunha-se como uma "defesa contra injuria do tempo e pelo fato de não estar bem, como é o caso de tantas outras, por esse Brasil, agora sob a proteção de um órgão que lhe assegure a pureza"11

$\mathrm{O}$ argumento em prol da proteção da capela se fundamentou no interesse público pela conservação da história e a memória para seus habitantes. Desde essa ótica, a capela de São Gonçalo do Amarante se inscreve na categoria dos "lugares da memória" (NORA, 1993), aos quais se atribui a propriedade de suportar a mesma sob o argumento de que objetos materiais podem agir como análogos da memória e, assim, desempenhar o papel de suportes de uma impressão que sem intervenção tende a erodir-se, conduzindo ao esquecimento.

Ainda que autores como Forty (1999), venham a problematizar a universalização desse pressuposto, ele é tão arraigado na tradição intelectual do ocidente que é importante frisar a

\footnotetext{
${ }^{11}$ À época Marcelo Moreira, diretor da Divisão do Patrimônio Histórico e Artístico do Estado de Guanabara afirmou: "torna-se necessário sua preservação para darmos às gerações futuras uma mostra da arquitetura de então, e sobretudo a prova de nosso zelo no resguardo do passado histórico (INEPAC, 2014)"
} 
dificuldade para pensar e praticar a memória fora de tais referentes materiais no nosso contexto. Assim, a restauração da Capela de São Gonçalo do Amarante estaria, em princípio, em sintonia com as abordagens mais convencionais desta temática, as quais ressaltam a importância de imagens espaciais na conformação da memória (HALBWACHS, 2004; NORA, 1993; YATES, 2007). Um dos desdobramentos dessa proposição traduz que quanto mais durável o objeto, maior sua capacidade de sustentar memória e evitar o olvido.

Compreendem-se assim os esforços e investimentos sociais e econômicos na recuperação de lugares e edificações associados ao passado. Contudo, segundo Forty (1999) e Küchler (1999), nem sempre monumentos operariam no sentido de fazer lembrar, e o desgaste da matéria não transita diretamente para o esquecimento. As fissuras desse modelo encontram-se, por exemplo, no papel das ruínas no avivamento das lembranças e na criação de novas formas de rememoração que arquivos e etnografias revelam. No caso da capela São Gonçalo do Amarante a estabilidade da memória parece não ter dependido, em princípio, de seu suporte material, ao contrario, a degradação que por décadas afetou a estrutura material esteve longe de se acompanhar pelo esquecimento.

O processo de tombamento passou por uma revisão da história da capela e da região. A documentação do processo de tombamento ${ }^{12}$ nos permite ter um entendimento dos elementos que foram considerados para propor seu tombamento, trata-se da própria história local vinculada à fundação da cidade de Rio de Janeiro e à inserção da região no ciclo das plantações de açúcar, características que tornam o lugar emanador dos atributos da nação e integrante das "narrativas nacionais", narrativas que muitos dos moradores de Camorim sabem de coração, para ufanos explicar "este aqui é um lugar com muita história".

São Gonçalo de Amarante foi uma capela construída pelo Prelado Matheus da Costa Aborim em 1625, era parte do Engenho de Camorim também chamado Pirapitingui, um dos primeiros a ser movido mediante energia hidráulica na transformação da cana em açúcar naquele período. Propriedade do sesmeiro português, Gonçalo Correia de Sá, filho de Salvador Correia de Sá, o segundo governador de Rio de Janeiro e sobrinho de Estácio de Sá, fundador da cidade de Rio de Janeiro. Quando Vitoria de Sá, filha de Gonçalo se casou com Luiz Céspedes herdou as terras e escravos do seu pai. ${ }^{13}$ Ao morrer, viúva e sem filhos em 1667 Vitoria doou seus pertences ao Mosteiro de São Bento (SILVA NIGRA, 1950). ${ }^{14}$

Ao tomar posse do engenho e dos escravos, os monges beneditinos colocaram na capela

\footnotetext{
${ }^{12}$ Não há no arquivo do processo de tombamento dados referentes aos promotores da ação, nem informações sobre a comunidade local da época.

${ }^{13}$ No testamento, dona Vitoria manifestava " Declaro que as terras da Pabuna até o mar e correndo a costa athe junto da Guaratiba com seus montes, campos restingas lagoas e ríos sao meos que os herde de meus país e avos e algumas destas terras das Pabuana athe meu curral da medida tenho dado por obra pia, o q meus testamenteros guardarão" sic (SILVA NIGRA, 1950).

${ }^{14}$ Uma vez nas mãos dos beneditinos, a terra foi dividida para facilitar a administração. Uma parte conservou o nome de Camorim, outra passou a se chamar Vargem Pequena e uma terceira ganhou o nome de Vargem Grande.
} 
a imagem de São Bento e denominaram o templo Nossa Senhora de Mont Serrat e introduziram as imagens de Santa Anna e Nossa Senhora do Pilar, mas elas foram transferidas em 1776 para a capela da Vargem Pequena que começou se chamar Nossa Senhora de Mont Serrat, com o que a capela de Camorim recuperou seu primeiro nome. Além da construção, a capela guardava as obras dos escultores Simão da Cunha e José da Conceição, autores das imagens da Nossa Senhora do Rosário, Nossa Senhora da Conceição, São Gonçalo e São Bento.

Imagem 6 - Capela de São Gonçalo do Amarante, desenhada por Magalhães Corrêa

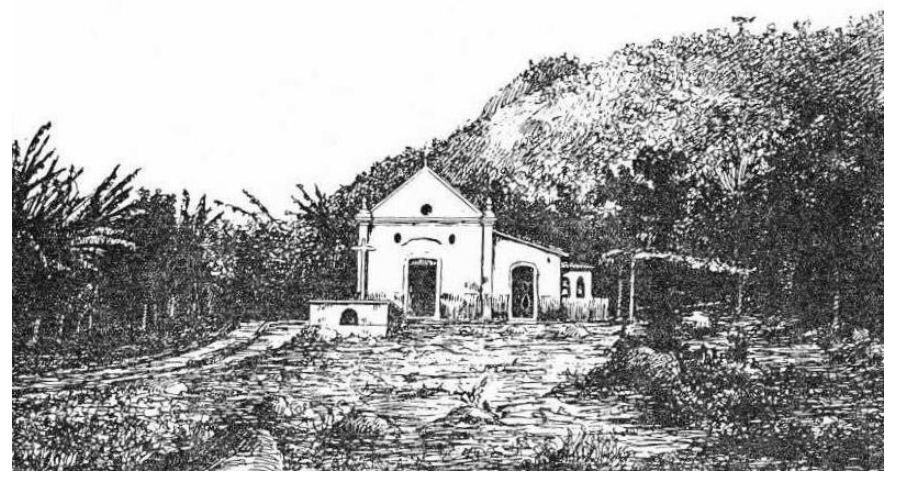

Fonte: Sertão Carioca 1936.

Entre sua fundação e tombamento poucas são as notícias da capela, sabe-se que os frades beneditinos hipotecaram as terras ao Banco de Crédito Imóvel no final do século XIX. O Banco se tornou o único proprietário das terras, desde Pavuna ao pontal de Sernambetiba, e a capela manteve-se em pé. Para os moradores a referência histórica da capela mais importante e difundida se encontra no trabalho de Magalhães Corrêa ${ }^{15}$, autor de crónicas sobre a região publicadas entre 1920 e 1930 no Correio da Manhã. Ali o autor representa a capela de um modo, que ao dizer de muitos moradores não perde vigência.

A igreja toda branquinha com faixas azuis cobertas de telha canal, lembrando os tempos coloniais. Feita de pedra e barro, tem uma porta de entrada, com humbraes de cantaria e ao lado a entrada da sacristia e logo a seguir os dois sinos de bronze, do tempo de sua fundação. No interior do templo, um arco sustentado por duas pilastras e no altar, ao centro, São Gonçalo de Amarante à direita São Bento e à esquerda N.S. da Conceição; logo abaixo o Sagrado Coração de Jesus e o tabernáculo

\footnotetext{
${ }^{15}$ Segundo Engemann os escritos de Magalhães Corrêa, que seriam editados mais adiante no livro $O$ Sertão Carioca, influenciaram de forma decisiva a idealização de Camorim e seu entorno como uma verdadeira terra prometida, "onde a cordialidade e a sabedoria do brasileiro estariam a salvo da avassaladora transformação da sociedade". Até faz pouco tempo, os bairros de Camorim, Vargem Grande e Vargem Pequena eram assemelhados a recantos rurais e assim vendidos no mercado imobiliário para as classes abastadas que procuravam casa campo e sítios (ENGEMANN, 2010, p. 67).
} 
com o Santíssimo Sacramento. À esquerda duas seteiras por onde entram luz e ar, e pias de pedras embutidas na parede. A sacristia tem pia de pedra, mesa e escadaria para o púlpito. Em frente à igreja existe um cruzeiro feito de cimento sobre rochas, e uma cruz de madeira: nesta base está um nicho, a "Capela de Santa Bárbara" onde depositavam esmolas quando a igreja está fechada (MAGALHAES CORRÊA, 1933, p. 4).

\section{A capela de São Gonçalo do Amarante: de objeto do meio a lugar heterotópico}

Contudo, a imagem que Magalhães Corrêa imortalizou não tem sido tão estável assim. $O$ que os dados de arquivo e os recortes de imprensa revelam é que a igreja passou por ciclos de auge, decadência e profundas transformações. Nas primeiras décadas do século XVIII sofreu algumas modificações, a mais importante ocorreu entre 1795-1800, quando se alterou seu volume e o espaço interno porque elevou-se o telhado da nave. Com a saída dos beneditinos em 1891 a igreja ficou abandonada até 1907 (MAGALHAES CORRÊA, 1933) quando, de acordo à Mitra Arquiepiscopal do Rio de Janeiro, o Padre Climério obteve a ajuda da arquidiocese de São Sebastião do Rio de Janeiro e resgatou a igreja das ruínas para garantir o ressurgimento das atividades religiosas não sem certas dificuldades ao longo das décadas seguintes.

Ao contrário do que se poderia pensar, o tombamento da capela em 1965 não foi infalível para superar os problemas da sua manutenção. Até parece que a sua inscrição no Livro de Tombo das Belas Artes do Estado de Guanabara surtiu um efeito totalmente inesperado. Logo depois do decreto de tombamento a igreja caiu no maior abandono e a degradação arquitetônica foi tão extrema, que ficou fechada entre 1972 e 1990. A própria arquidiocese a tinha abandonado a sua sorte e os fieis sem pároco por perto nada podiam fazer. Na lembrança de Dona Leeni Castilhori de Souza que mora ha 45 anos em Camorim e que exerceu como capelã e coordenadora da comunidade eclesial de base até 2011, a igreja foi depredada e invadida e várias das imagens foram roubadas, outras tantas foram tiradas para sua proteção, porém sua atual localização é um mistério.

Quando dona Leeni passou a residir no bairro a igreja estava fechada e a atividade eclesiástica acontecia eventualmente, quando o Padre Ambrósio ia desde o Tanque a Camorim para oficiar. No final dos anos 1990 alguns moradores promoviam missas no colégio que estava sobre a estrada dos Bandeirantes, foi quando o padre Rino de Curicica começou oficiar que surgiu a ideia de retomar a igreja.

Naquele momento a igreja tinha se tornado lar e abrigo de seus cuidadores e depois de uma família. O estado de abandono era de iconoclasmo puro, o sino tinha sido roubado 
assim como a imagem de São Gonçalo que estava no altar mor, em cujo lugar o zelador instalou um televisor. Os bancos dos fieis foram transformados em sofás e camas improvisadas. O capim crescia no pátio da igreja enquanto pássaros, ratos e cupins aninhavam, tornado a igreja "objeto do meio", híbrido entre natureza e cultura (LATOUR, 1994). Uma notícia de jornal em 1986 descreve assim o estado da capela:

Sua existência esta sendo seriamente ameaçada. As poucas madeiras que lhe restam estão comidas pelos cupins, as outra foram roubadas. A sacristia esta sem condições de uso, o sino foi roubado, o altar esta quase despencando e o confessionário mal consegue manter-se em pé. Apenas dois bancos de madeira e algumas imagens de santos na parede é que estão aparentemente inteiros. O padre Tacil Tavares, há mais de dois anos, vai todos os domingos até o local para rezar a missa ao lado, ou quando chove na casa de algum morador. Ele fala do valor histórico da capela e no movimento da associação de moradores que pretende solicitar o seu tombamento. (O Globo. 21 ago. 1986).

No mesmo jornal, o padre Rino depunha:

eu sei que uma arquiteta iria até lá para ver a capela. A finalidade é o tombamento, acho que o tombamento só vale a pena se carregarem a capela para outro lugar, porque hoje em dia ninguém gosta de fazer o sacrifício e o percurso para chegar lá é longe demais (O Globo. 21 ago.1986).

O que tal noticia reforça é que o tombamento não somente não salvou a capela de estar inserida no processo vital e de desgaste de materiais, senão que o mesmo, ocorrido em 1965 era desconhecido.

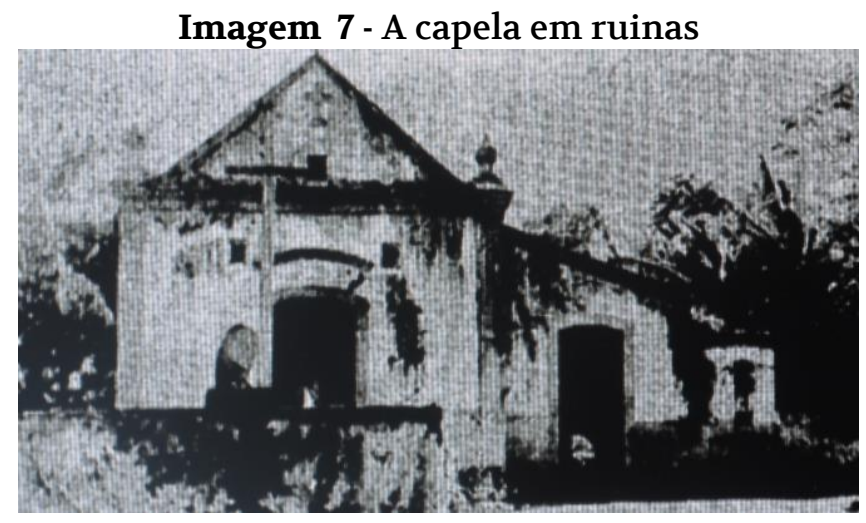

Fonte: O Globo 07 out. 1973 
Para a comunidade católica local a igreja em ruinas não significava tanto uma perda da memória, senão de tempo. Segundo dona Leeni, as pessoas tinham que ir longe demais para assistir a missa, tendo que se deslocar até Tanque, Curicica ou Taquara. Se bem os pontos de referencia de uma época longínqua podem ser integrados aos sentimentos de filiação e de origem fazendo que aqueles que vivem nos locais dessas heranças extraiam um orgulho especial (POLLAK, 1989), é justo precisar que naquele momento a apreensão era a falta de um local adequado para levar a cabo os ofícios religiosos, em outras palavras a definição nativa patrimônio priorizava sua utilidade religiosa antes que sua história e memória, equação que vem sendo invertida pelas demandas quilombolas.

Algumas das pessoas entrevistadas lembram que parte da iniciativa na retomada da igreja proveio da moradora Vera Cavalcanti, a benfeitora residia à época no Sitio Cronus, o mesmo onde anos depois se levantou o muro da discórdia. Vera promoveu algumas ações básicas, incentivou mutirões e pagou algumas despensas. Foi em nome da sua fé que os paroquianos se sentiram motivados e começaram fazer festas e outros mutirões para conseguir dinheiro para reparar danos e pintar a igreja. Uma ação importante dos fieis foi encontrar um local para a família que morava na igreja, mais uma vez seu Moacir cedeu um outro espaço no seu terreno e ali na favela do Marinbondo, Creusa e Jorge montaram um barraco e deixaram a capela.

A participação dos fieis na restauração da igreja foi muito intensa, e para muitos é motivo de orgulho ter contribuído com uma obra que testemunha o trabalho coletivo. Dona Leeni manifestou que a causa da igreja representou tanto para ela, como para outros fieis "a maior das alegrias, todos juntos trabalhando por algo que nos representava". No meio do anos noventa os restauradores empíricos perceberam que era preciso fazer algo mais estrutural; quando quiseram trocar o telhado, notaram que essa ação seria insuficiente para recuperar a capela, e que o procedimento requeria, além recursos consideráveis, uma assessoria técnica mais especializada.

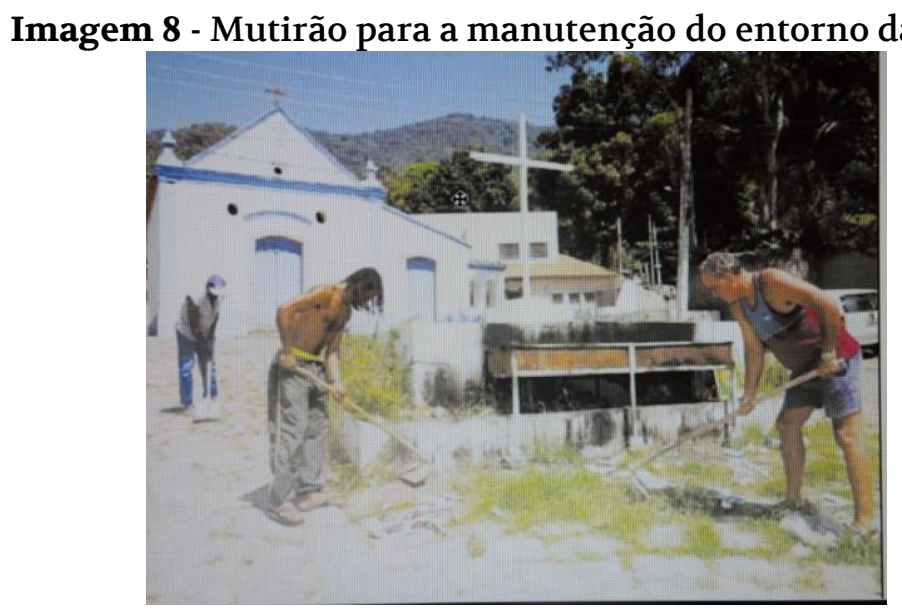

Fonte: O Globo $06 \mathrm{dez} .2001$. 
Foi em 1996 quando os moradores contataram o INEPAC. Segundo dona Leeni, o professor e geógrafo Rogerio Ribeiro, também morador do bairro, apresentou o projeto para realizar a reforma, porém ao igual que a Igreja católica, proprietária da capela, a instituição não tinha recursos para fazer a obra. Entretanto, o INEPAC é lembrado por ser uma das poucas vezes em que a comunidade se incorporou ativamente do processo e o Estado deixou sentir sua presença num bairro que foi crescendo organicamente e sem nenhuma política urbana.

A responsável pelo financiamento do restauro foi a construtora São Fernando Patrimonial, como resultado de uma aliança que Eduardo Paes, subprefeito da Barra á época, realizou com essa empreiteira, num emaranhado jogo de troca de favores. Uma das minhas entrevistadas confirmou "era o momento em que Paez se candidatava como deputado federal, e ele vinha muito por aqui, entrava na casa da gente, foi ai quando falamos para ele, a gente te consegue os votos, mas você ajuda a gente com a capelinha"16.

Durante 4 anos os moradores de Camorim conviveram e participaram ativamente do trabalho de recuperação, em cada reunião dona Leeni fazia bolo e café. A comunidade dava dinheiro para comprar a comida dos pedreiros, dona Leeni e dona Alcira eram as encarregada de fazer os almoços. É um tempo lembrado pelos mutirões organizados nos fins de semana para capinar a frente da capela e para trazer as pedras do rio que hoje calçam o largo da capela, toda uma interação das pessoas sobre o entorno. Hoje se lembra com carinho às pessoas que participaram dos cuidados da igreja e sua custodia como dona Alcira de Almeida, recentemente falecida.

Já nos relatórios do INEPAC sobre o processo revelam a lentidão do processo, as pressões da comunidade para os avanços, os problemas técnicos enfrentados para conseguir compaginar uma restauração arquitetônica que fora "fiel à história", e que ao mesmo tempo se adequasse às necessidades mais modernas como água encanada, instalações de luz trifásica, telefone etc.; além do ajustamento às mais recentes normas de segurança em construção civil.

Os agentes envolvidos na restauração não pouparam esforços por trazer à "vida" a capela em ruínas, e a restauração viu-se desafiada pela procura e eleição dos materiais que substituíram aqueles originais que já não se conseguiam mais, ou cuja obtenção representava um ônus extra para a empreiteira tais como as telhas francesas e os mastros de madeiras nobres. Dona Leeni relata que o INEPAC era muito exigente, "eles sempre estavam fiscalizando os materiais escolhidos, mas nem sempre tínhamos a sorte de achar tudo nos

\footnotetext{
${ }^{16}$ A atuação de Paez se antecipava ao estilo urbanístico-político que o mesmo, mas depois prefeito do Rio de Janeiro, repetiu e implementou para preparar a cidade para a Copa do Mundo 2014 e os Jogos Olímpicos 2016, ainda sem abandonar os velhos esquemas clientelistas
} 
padrões deles".

As discussões encontradas nos relatórios também se debruçam sobre a conveniência de reaproveitar elementos como vigas, paredes e chão e como poderiam ser combinados com materiais novos, lamentavelmente nem todas as decisões a respeito foram levadas aos relatórios de visitas do INEPAC. Entretanto, os participantes lembram que as discussões sobre temas como materiais e cores eram eternas, enquanto a urgência dos fieis era um templo para receber a comunhão. As anedotas ao respeito são inúmeras, seu Moacir disse que conheceu a igreja toda de branco e que foi após o restauro que aquele azul nas bordas apareceu, "nem tinha pensado que podia ser diferente, o importante era ter local para missa, fazer as procissões".

Outros detalhes melhor documentados são as imagens de Nossa Senhora da Conceição, São Gonçalo e São Bento que ocuparam o altar foram encomendadas a um artesão de Olinda $\mathrm{PE}$, fabricadas em resina e em estilo barroco, elas reproduzem os modelos originais, "era a irmã Cristina, do convento Belém, a que tirava as fotos e mandava fazer" Conta dona Leeni. Já os candelabros foram trazidos de Minas Gerais e os lustres encomendados a um atelier em Benfica. As minúcias do processo nos levam a estimar os sentidos das palavras restauração e restituição. O que foi o que nessas circunstancias, com esses recursos foi possível fazer? A prioridade residia em permitir a função religiosa ou no restauro da forma original? Ao parecer essa não foi exatamente uma escolha e ambas ações terminaram se misturando. Como afirma Gonçalves (2005, p.5) o acesso que o patrimônio possibilita ao passado não depende totalmente de um trabalho consciente de construção no presente, mas, em parte, do acaso. $\mathrm{Na}$ reconstrução intencional do passado, este se revela contra si mesmo incontrolavelmente.

Em síntese, o processo de restauro encorpa mais que uma volta às origens, a recomposição de um lugar a partir de justaposições e simultaneidades do próximo e do longínquo, do lado a lado e do disperso (FOUCAULT, 2006), assim como do cruzamento de memória e histórias e do sagrado com os cultos populares que hibridizam a relação entre tradição e modernidade, técnicas de construção e necessidades atuais, na tentativa de estabilizar num único ponto o colapso do passado, o presente e futuro.

\section{Da paisagem incorporada à paisagem estática e vice-versa}

É do período da restauração da igreja que se registra a inquietação do INEPAC com a ambiência da mesma e as interferências negativas na ordem da segurança, integridade estética e visibilidade que alteraram sua inserção no que foi definido como o "conjunto 
panorâmico e urbanístico circunjacente" (RIO DE JANEIRO, 1981). O que essas preocupações do INEPAC revelam em si é uma noção de paisagem, trata-se de uma elaboração conceitual enquadrada nos termos de uma percepção pictórica que estima a paisagem como algo concluído e estático que se vê desde fora.

Assim, a serie de problemas com os que o INEPAC começou a lidar à época, eram construções irregulares que interferiam com a "valorização" da área do entorno do monumento religioso. Casas de dois andares no fundo da igreja, puxadinhos e lajes prémoldadas, pilares etc, começaram a ficar no olho dos técnicos do INEPAC. Essas construções foram tratadas como infrações penais e delas solicitava-se imediata demolição. Ao longo do tempo e até hoje o "infrator" era o mesmo proprietário que construía e demolia, avançava e recuava ao vai vem das cartas de alguns moradores, as fiscalizações, as notificações e a falta de instrumentos punitivos das autoridades para enfrentar o descaso do suposto transgressor (INEPAC, 2014).

Entretanto ao tempo que se impediam sem sucesso o avanço dessas construções "ilegais", os fies projetavam a construção de um centro de catequese contiguo e também um projeto de ajardinamento. Dona Leeni assegura "o INEPAC queria outra coisa, mas as necessidades da comunidade eram outras. A comunidade estava viva e precisávamos de mais espaço". Com o reflorescimento da vida católica, a igreja tinha ficado pequena para as atividades eclesiais e fazia-se necessário a edificação de um prédio anexo.

A elaboração desse projeto esteve a cargo do arquiteto Rui Velloso do INEPAC, "a integração ao ambiente" foi a inquietação que guiou o desenho, "visando o aproveitamento equilibrado da área lateral disponível". Foi assim como "a altura da fachada frontal do anexo foi alterada de forma a esconder parte da edificação vizinha existente aos fundos que interfere negativamente no ambiente do bem tombado, buscando minimizar visual indesejado pela sua presença" (INEPAC, correspondência interna).

Longe de pretender, com isso, participar de - seguindo as palavras de Latour - uma "crítica rasa", concentrada em denunciar as contradições e ambiguidades das restaurações arquitetônicas e suas inevitáveis atualizações, os dilemas enfrentados permitem uma aproximação às narrativas e práticas que organizam tais intervenções e, dessa maneira, conhecer os contornos que o patrimônio, enquanto categoria nativa, enfrenta aos contornos oficiais do mesmo e as negociações político-administrativas que dele se servem (GONÇALVES, 2005).

Exemplo das negociações em torno a gestão do patrimônio se encontra no financiamento do prédio anexo que a comunidade estava requerendo. Para a sua construção nem a Igreja, nem o INEPAC, nem muito menos a comunidade tinham recursos financeiros para executar o projeto. A gestão de Eduardo Paes serviu de novo para a intermediação de uma outra parceria, desta vez com a empresa GlaxoSmithKline, cuja sede localiza-se sobre a 
estrada dos Bandeirantes. A outra negociação necessária para a edificação do prédio de catequese anexo foi feita com as pessoas que moravam no terreno contiguo à igreja. "Houve que convencê-los e ainda lhes construir uma casa para que pudessem abandonar o local" conta dona Leeni.

François Hartog adverte que as relações conflituosas com os patrimônios servem para denotar, antes que nada, o tipo de relação que uma sociedade estabelece com o tempo. É dizer que as sociedades constroem "regimes de historicidade" bem seja para imitar o tempo, conjura-lo, extrair dele prestigio, passar por cima dele, ou apenas revisitá-lo (HARTOG, 2009, p. 196). Contudo, essa diversidade de relações não propõe uma exclusão das umas ou das outras, nem uma sucessão cronológica, sendo possível deparar-se sobre um mesmo lugar e tempo com diferentes formas de relação e delimitação do patrimônio e o tempo.

Uma das sobreposições de interesses, usos e relações com o entorno da igreja se deu, por exemplo quando o INEPAC cogitou, após o restauro, a realização de um projeto paisagístico na frente da capela como forma de gestar a ambiência do bem tombado. Então, o órgão fez contato com a Fundação Parques e Jardins e com um par de paisagistas, porém o projeto nunca chegou a sair do papel e para dizer verdade a comunidade não chegou a se importar, pois o largo da igreja mais que a ambiência de um bem tombado é uma rua, um espaço de circulação usado pelos habitantes para transitar seja de carro, moto, bicicleta ou de pé. A rua é o lugar de encontro em festas juninas e feijoadas comunitárias, e hoje em dia é o local de prática da capoeira e das aulas de dança que Adilson ministra aos jovens do bairro, é o pedaço onde se pode sentar para tomar cerveja num final de tarde, é a referência para os encontros e um pouco mais na frente é ponto de vans e às vezes o local é estacionamento de carros maiores.

Se ante esses atos cotidianos de usos e construções informais no entorno do templo o INEPAC perdeu o controle, a paralisia do órgão frente ao desastre que o PEU das Vargens promoveu foi maior, nada pode fazer. Para os vizinhos a autêntica catástrofe se concretou com a venda do Sitio Cronus, aquele do lado esquerdo da igreja, à Construtora Cyrela em 2013, em dezembro desse ano começou o que muitos já temiam, a construção de um condomínio residencial multi-familiar com vários blocos. O nome do projeto é Grand Club Verdant e em seu outdoor prometia ser o primeiro clube residencial da região "cercado pela natureza". A diferença das outras intervenções na paisagem é que desta vez os moradores não participavam, trata-se de um momento no que a "incorporação" dos habitantes na paisagem ficou marginalizada na medida em que não possuem nenhum controle sobre o que esta acontecendo. 


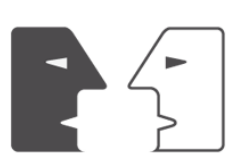

ANTÍTESES

Imagem 9 - Foto do outdoor da Cyrela para promover seu projeto arquitetônico Grand Club Verdant.

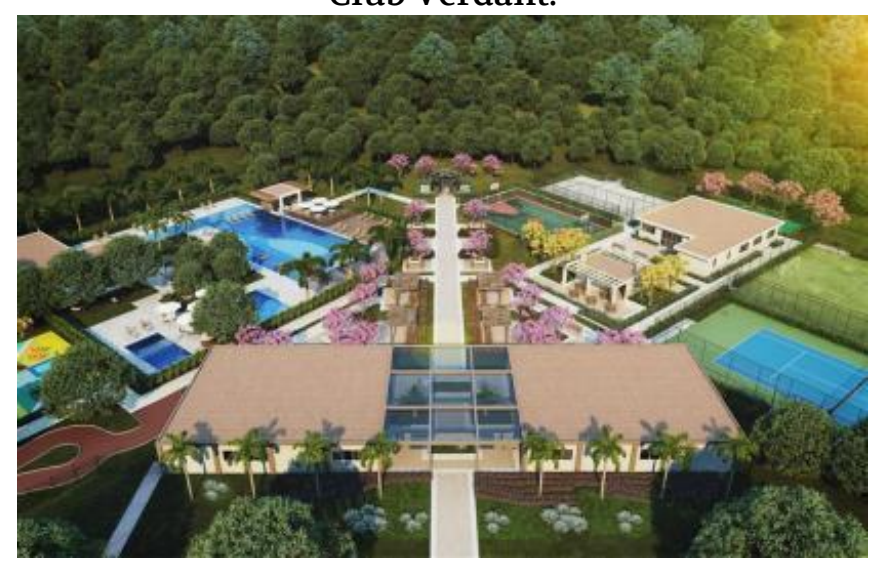

Fonte: Luz Stella Rodríguez 10/06/2014

O desmatamento para dar inicio à terraplanagem do lote durou várias semanas, resignados, só restou para os habitantes de Camorim a impotência frente ao som das serras, era esse som tudo o que ouviam além do silêncio das autoridades ambientais, inutilmente contatadas. O sentimento em geral foi de tristeza e vazio, "mais de um por aqui chorou" contava Adilson. Quando os órgãos de controle responsáveis apareceram, dois meses depois, não ficava uma única arvore em pé. Rosaline Almeida descreveu assim a mágoa que a embargava:

O que dizer quando você se sente impotente diante de uma luta que há anos espera um resultado, e vê que um pouco de dinheiro a mais compra o privilégio de fazer o que bem entender com um lugar tão rico de história, fauna e flora? Estou muito triste, a única área que ainda guarda vestígios da época da escravidão, está sendo apagada para construir mais prédios, será que ainda existe alguém que queira mostrar para o mundo a cultura linda que o Brasil tem, ou só usa isso como fachada pra ganhar mais dinheiro? Sitio Cronus perdendo muitas árvores mais velhas do que qualquer morador do Camorim, para servir de morada, mas para quem? ${ }^{17}$

${ }^{17}$ Depoimento em 23/12/2013 
Imagem 10 - Desmatamento do Sitio Cronus, comprado pela construtora Cyrela

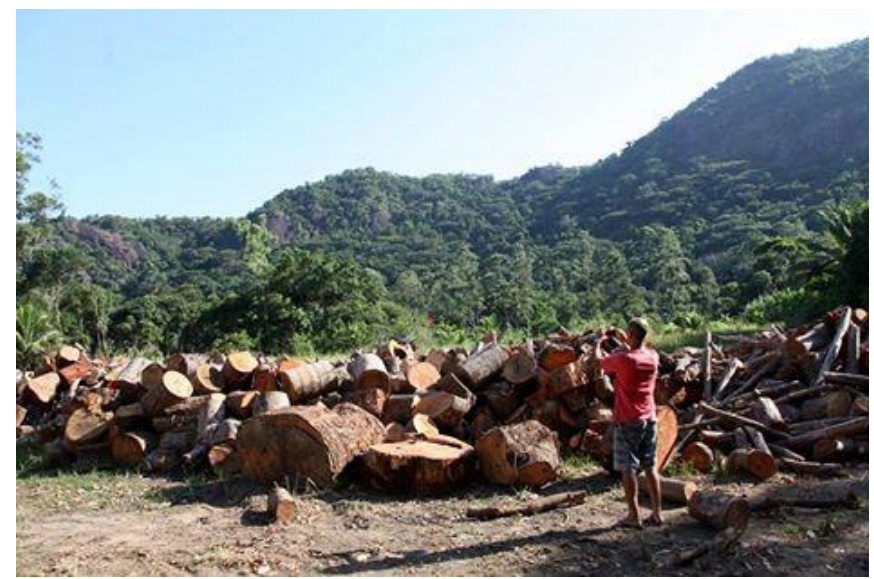

Fonte: Adilson Almeida 06/01/2014

\section{Imagem 11 - Avanço das Obras da Cyrela}

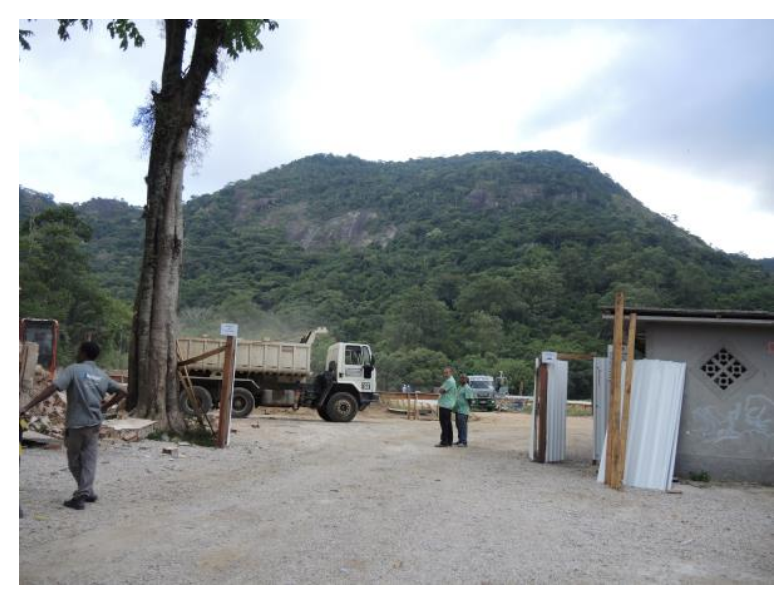

Fonte: Luz Stella Rodríguez 23/05/2014

Segundo Adilson, os tratores também aterraram o que sobrou de um dos prováveis locais da senzala do engenho de Camorim e o temor é que, pela proximidade, a obra possa comprometer a igreja. E é que nesse contexto a igreja tem se tornado um importante elemento simbólico das reivindicações quilombolas, é nos seus arredores onde se praticam atividades como capoeira e se comemoram datas de importância com feijoadas comunitárias e danças. A logomarca das camisetas dos praticantes de capoeira simbolizam essa a apropriação, trata-se de umas mãos escravas encadeadas que guardam a capela. Alguns moradores fizeram denúncia à Ouvidoria do Ministério Público, ressaltando o desrespeito à memória, à cultura e ao patrimônio histórico e ambiental carioca. "Eles querem acabar com a nossa identidade começando a destruir as marcas desse território. Mas a nossa memória não vai ser destruída", afirmou no seu momento Sonia, uma moradora do 
Alto Camorim. Essas colocações não dizem respeito apenas a um conhecimento que fala sobre a paisagem como um objeto, mas desde a paisagem, enquanto condição de ser no mundo, onde se entrelaçam a cultura, a natureza e o sujeito (HIRSCH; O'HALON, 2003).

Imagem 12 - Dança de Makulele no anexo da Igreja de São Gonçalo do Amarante

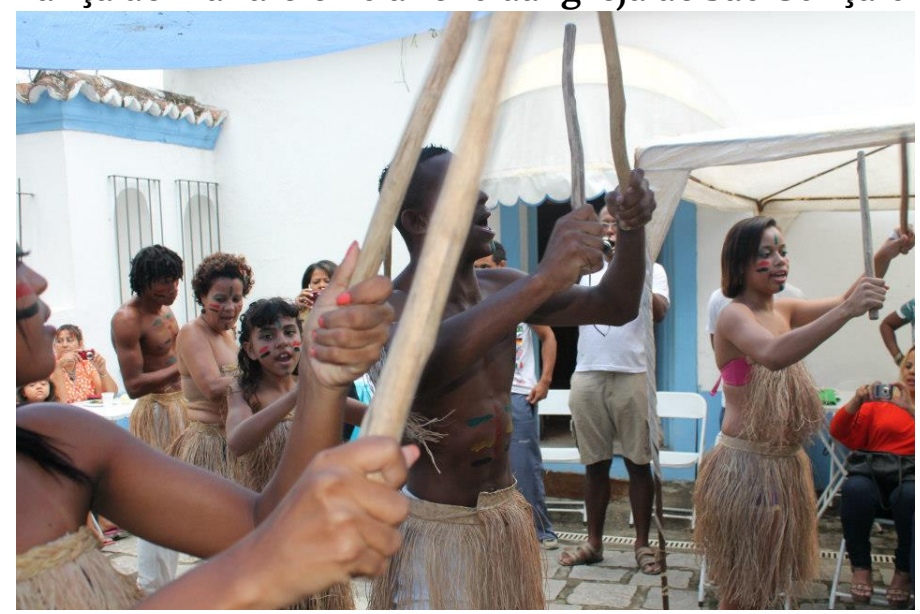

Fonte: Luz Stella Rodríguez 20/11/2012

Imagem13 - Detalhe da camisa usada pelos capoeiristas

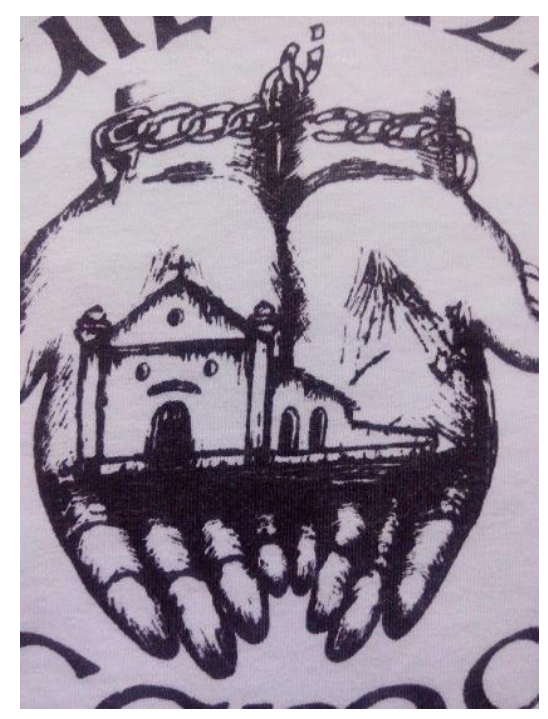

Fonte: Luz Stella Rodríguez 20/22/2012

A construtora pela sua parte informou que possuía as licenças de demolição e remoção de árvores necessárias, expedidas pelos órgãos competentes. Ainda confirmaram que não existia nenhuma ruína no imóvel, e que cumpriram devidamente com todas as medidas compensatórias originadas da licença ambiental. 
Compreende-se aqui em outras palavras o medo de perder a paisagem que os moradores expressaram no começo desta pesquisa. Essa perda vai da mão do avanço da densidade demográfica na região, o desaparecimento do espaço público livre e a multiplicação de ruas sem vitalidade demarcadas por muros de condomínios. $\mathrm{E}$ é paradoxalmente ao interior desses empreendimentos onde se encontram as estruturas urbanas básicas pelos que os habitantes têm lutado sem muito sucesso.

Assim, enquanto o pleito colocado pela ACUCA e demais moradores do Alto Camorimjunto à Prefeitura, para ter no local um espaço para desenvolvimento de atividades de cunho cultural e lazer vem se arrastando há anos, a Prefeitura parece ter mais disposição em estender as mãos para as empresas do ramo imobiliário.

Nesse confronto de visões fica claro que o que as construtoras e a Prefeitura não têm entendido é que esses espaços vazios, ainda existentes no bairro e com certeza nos demais locais intervindos é que eles possuem identidade e significados e não são apenas tabula rasa para a especulação do mercado imobiliário, a qual trata o espaço considerando apenas taxa de ocupação, gabarito e índice de aproveitamento do terreno. Como argumenta Adilson, "não é só trazer o progresso pra cá, é preciso manter a história que existe nessa localidade". Daí que nas falas as pessoas reclamem por uma paisagem que possam fazer parte integralmente.

A paisagem pensada como o horizonte de convergência dos corpos humanos e nãohumanos com o ambiente que conduz a corporeidade da paisagem (embodiment landascape) (INGOLD, 2000), não é contraria às definições dos residentes que consideram que a paisagem também esta configurada pelos mutirões de final de semana, a fé das organizações religiosas, as caminhadas pelas trilhas da floresta, ou os esforços para o resgate cultural promovidos por organizações como ACUCA. Como confirma Rodolfo, geógrafo e também morador do bairro "há todo um cotidiano que também é um patrimônio que não merece ser transformado em condomínios e shoppings áridos e insensíveis, preocupados apenas com o lucro do investimento".

O assunto do PEU das Vargens esta longe de ser uma discussão terminada, e é hoje um marco das questões paisagísticas e patrimoniais da zona oeste do Rio de Janeiro. Em novembro de 2013 o prefeito Eduardo Paes criou a Área de Especial Interesse Ambiental (AEIA) (RIO DE JANEIRO, 2013) dos bairros de Vargem Grande, Vargem Pequena, Camorim e trechos da Barra da Tijuca e do Recreio. Excluindo as obras destinadas ao parque e vila olímpicos, tratou-se de uma decisão que suspendia os processos de concessão de novas licenças de empreendimentos com base nas regras do PEU para estudar meios de proteger o meio ambiente da região levando em conta os ecossistemas naturais existentes. Para muitos e tal como se demonstra aqui foi uma medida tardia. 


\section{Conclusão}

As transformações que vêm modificando a paisagem de Camorim, a partir da aprovação do PEU das Vargens, foram abordadas sob um víeis que pretendeu examinar as mudanças acontecidas tendo em consideração a percepção dos moradores do bairro. Para isto a noção de paisagem foi útil para entender tanto as perspectivas nativas como os pontos de vista externos localizáveis no atuar do INEPAC, a Prefeitura do Rio de Janeiro e as construtoras. Nessa paisagem em mudança localiza-se a igreja de São Gonçalo do Amarante, uma construção cheia de significados para a comunidade local. A ela e sua materialidade se ancora a comunidade como símbolo de permanência e continuidade, como suporte escolhido para ser o deposito das memórias. Entretanto, como vimos, ela própria também foi sendo modificada pelo rigor da ação do tempo e pelo abandono a que foi submetida temporalmente. A estabilidade a ela exaltada deve-se a fato de permanecer no local e ainda cumprir sua função original, porém no marco das reivindicações étnicas do grupo quilombola novas simbologias de prática e sentido lhe são associadas.

Nesse sentido veio a tona a noção de heterotopia de Foucault (2006), definida como capacidade de construir sobre o construído, de alterar a significação de um espaço a partir da imaginação, de projetar em termos emocionais um significado que vai além do estritamente dado pela dimensão física e funcional da arquitetura. Essa heterotopia se vê reforçada quando examinamos o processo de tombamento da igreja e de posterior restauração. A descrição desses procedimentos também foi útil para nos confrontar com definições e usos do patrimônio que ao não se ajustar às categorias oficiais da administração do patrimônio desestabilizam classificações mostrando as fissuras do modelo ocidental de memória e patrimonialização.

A categoria nativa desse patrimônio se definiu, num primeiro momento, na necessidade de recuperar um espaço para o culto católico, mais adiante na necessidade de espaços para atividades comunitárias gastronômicas como feijoadas e lúdicas como dança e capoeira. No atual momento as memórias históricas e o valor de permanência e continuidade são o suporte ao que se ancoram os habitantes que repudiam as bruscas alterações na paisagem e na procura de continuidade, numa operação que equaciona a permanência da paisagem com a própria permanência desses moradores na paisagem.

A paisagem em mudança não é um contraponto para uma memória que se mantem, pois ela também não é estável e está em processo continuo de transformação. A capela de São Gonçalo do Amarante, igual à paisagem, está em movimento, em processo continuo de transformação, mas mantida em pé pelo esforço e trabalho cotidiano da preservação. 


\section{Documentos - Jornais de Bairros - Matérias digitalizadas}

TOMBAMENTO, um gesto de muito amor ao passado. Rio de Janeiro, Matutina, Rio de Janeiro, 7 out. 1973. Matéria digitalizada pelo O Globo. Disponível em: $<$ http://acervo.oglobo.globo.com/busca/?tipoConteudo=pagina\&pagina=\&ordenacaoData= relevancia\&allwords $=\mathrm{s} \% \mathrm{C} 3 \% \mathrm{~A} 3 \mathrm{o}+\mathrm{gon} \% \mathrm{C} 3 \% \mathrm{~A} 7 \mathrm{alo}+\mathrm{do}+$ amarante\&anyword=camorim\&nowor $\mathrm{d}=\&$ exactword $=\&$ decadaSelecionada $=\&$ anoSelecionado $=\&$ mesSelecionado $=\&$ diaSelecionado => Acessado em:12 mar. 2014.

CAPELA se São Gonçalo foi até tombada, mas não tem assistência. Matutina, Rio de Janeiro, 15 jun. 1982. Matéria digitalizada pelo O Globo. Disponível em: $<$ http://acervo.oglobo. globo.com/busca/?tipoConteudo=pagina\&pagina=1\&ordenacaoData =relevancia\&allwords=s\%C3\%A3o+gon\%C3\%A7alo+do+amarante\&anyword=camorim\&nowo rd=\&exactword= >. Acesso em: 12 mar. 2014.

TOMBAMENTO não preserva capela. Matutina, Rio de Janeiro, 13 Jul. 1989. Matéria digitalizada pelo O Globo. Disponível em:<http://acervo.oglobo.globo.com/busca/?tipo Conteudo=pagina\&pagina $=1 \&$ ordenacaoData $=$ relevancia\&allwords $=s \% \mathrm{C} 3 \% \mathrm{~A} 30+$ gon $\% \mathrm{C} 3 \% \mathrm{~A} 7$ alo+do+amarante\&anyword=camorim\&noword=\&exactword=>. Acesso em: 12 mar. 2014.

MUTIRÃO se limpeza sem ajuda oficial. Matutina, Rio de Janeiro, 6 dez. 2001. Matéria digitalizada pelo O Globo. Disponível em:<http://acervo.oglobo.globo.com/busca/?tipo Conteudo=pagina\&pagina $=2 \&$ ordenacaoData $=$ relevancia\&allwords $=s \% C 3 \% A 30+$ gon $\% \mathrm{C} 3 \% \mathrm{~A} 7$ alo+do+amarante\&anyword=camorim\&noword=\&exactword=>. Acesso em: 12 mar. 2014.

\section{Bibliografia}

BERQUE, August. Paysage, milieu, histoire. Cinq propositions pour une théorie du paysage. Paris: Champs Vallon, 1994.

BRASIL, Rachel Paterman. Imagens de natureza e classificações de espaço: problematizando a "paisagem". In: REUNIÃO BRASILEIRA DE ANTROPOLOGIA, 29., 2014, Natal/RN.

Disponível em: <http://www.29rba.abant.org.br/resources/anais/1/

1402020763_ARQUIVO_29RBA_RPB.pdf >. Acesso em: 1 dez. 2014.

CAUQUELIN, Anne. L'invention du paysage. Paris: Quadrige/PUF, 1990.

CORRÊA MAGALHAES, A. O Sertão Carioca. Rio de Janeiro: Revista do Instituto Histórico e Geográfico Brasileiro, 1933. 
ENGEMANN, Carlos. As Marcas das Mãos. In: OLIVEIRA, Rogério Ribeiro de (Org). As Marcas do Homem na Floresta - História Ambiental de um trecho urbano de mata atlântica. Rio de Janeiro: Ed. PUC-Rio, 2010.

KOPYTOFF, Igor. A biografia cultural das coisas: a mercantilização como processo in: A. $A$ vida social das coisas: as mercadorias sob uma perspectiva cultural Arjun Appadurai (Org). Niterói: Ed. Universidade Federal Fluminense, 2010.

KÜCHLER, Susanne. The place of memory. In: The Art of Forgetting. New York: Oxford, Berg, 1999. p. 53-72.

FOUCAULT, Michel. Heterotopias. Ditos e escritos, Rio de Janeiro, v.3, p. 411-422, 2006. FORTY, Adrian. Introduction. In: . The Art of Forgetting. New York: Oxford, Berg, 1999. p. 1-18.

FRIDMAN, F. Donos do Rio em nome do Rei: uma história fundiária da cidade do Rio de Janeiro. Rio de Janeiro: Zahar, 1999.

GONCALVES, José Reginaldo Santos. A Retórica da Perda: os discursos do patrimônio cultural no Brasil. Rio de Janeiro: Ed. UFRJ, IPHAN, 1996.

_ _ _ _ _ . Ressonância, materialidade e subjetividade: as culturas como patrimônios. Horizontes antropológicos, Porto Alegre, v. 11, n. 23, p. 15-36, jan/jun., 2005.

HALBWACH, Maurice. A memória coletiva. São Paulo: Centauro, 2004.

HARTOG, François Regimes de historicidade. Presentismo e experiências do tempo. Belo Horizonte: Editorial Autêntica, 2009.

HIRSCH, Eric; O'HALON, Michael. The anthropology oflandscape. Perspectives on place and space. Oxford: Clarendon, 2003.

INEPAC. Histórico do Instituto Estadual do Patrimôno Cultural. Instituição. 2014. Disponível em:<http://www.inepac.rj.gov.br/index.php/home/instituicao>. Acesso em: 10 nov. 2014.

INGOLD, TIM. The perception of the environment: essays in livelihood, dwelling and skill. London: Routledge, 2000.

LATOUR, Bruno. Jamais fomos modernos: Ensaios de Antropologia Simétrica. Rio de Janeiro, Editora 34, 1994.

NAME, Leo; MONTEZUMA, Rita de Cássia Martins; GOMES, Elisa Sesana. Legislação urbanística e produção de riscos: o caso do PEU das Vargens (Rio de Janeiro, Brasil). Territorium, Coimbra, n.18, p 201-218, 2011. 
NORA, Pierre. Entre mémoire et histoire: la problématique des lieux. In: (Org). Les lieux de mémoire. Paris: Gallimard, La République 1984.

NORA, Pierre. Entre memória e história: a problemática dos lugares. Tradução de Yara A Koury. Projeto História, São Paulo, n. 10, p. 7-28, dez. 1993.

POLLAK Michael, Memória, Esquecimento Silencio. Estudos Históricos, Rio de Janeiro, v. 2, n.3, p. 3-15, 1989.

RIO DE JANEIRO. Lei $n^{\circ}$ 509, de 03 de Dezembro de 1981. Dispõe sobre o conselho estadual de tombamento e dá outras providências. Rio de Janeiro, 1981.

RIO DE JANEIRO. Decreto $n^{\circ}$. 37958, de 4 de novembro de 2013. Cria a Área de Especial Interesse Ambiental dos bairros de Vargem Grande, Vargem Pequena, Camorim e parte dos bairros do Recreio dos Bandeirantes, Barra da Tijuca e Jacarepaguá, nas XVI e XXIV Regiões Administrativas. Diário Oficial do Município do Rio de Janeiro, 5 nov. 2013. Ano 27, n.160.

SHAMA Simom. Paisagem e memória. São Paulo: Companhia das Letras, 2009.

SILVA-NIGRA, Clemente Maria da. Construtores e artistas do Mosteiro de São Bento do Rio de Janeiro. Salvador: Tipografia Beneditina, Arquivo da cúria metropolitana do Rio de Janeiro, 1950.

SOARES, Leonardo Dos Santos; RIBEIRO, Jayme Lúcio Fernandes. O que querer vender quer dizer: urbanização e conflitos de terra através dos classificados imobiliários do Sertão Carioca (1927-1964) Revista Ideas, v. 1, n. 1, p. 78-94, jul.-dez. 2007.

SOARES, Leonardo Dos Santos. A cidade está chegando: Expansão Urbana na Zona Rural do Rio de Janeiro (1890-1940) Revista Crítica Histórica Ano II, Nº 3, Julho2011

. Expansão urbana, mercado imobiliário e conflitos de terra no Sertão Carioca (1940-1964). Confluenze: Rivista di Studi Iberoamericani, Bologna, v. 4, n. 1, p. 263-281, 2012.

RIEGL, Aloïs. Le culte moderne des monuments. Son essence et sa genèse. Paris: Seuil, 1984.

YATES, Francis. As três fontes latinas da arte clássica da memória. In: A arte

clássica da memória. Tradução de Flavia Bancher. Campinas: Editora Unicamp. 2007. p. 17-46. 